\title{
Conference Series JCEB \\ The Planning and Implementation of Computer-based Games for Project Risk Management Education: A Preliminary Case Study
}

David Baccarini and Jianhong Xia (Curtin University, Western Australia)

Caulfield, G (Edith Cowan University, Western Australia)

\begin{abstract}
This paper reports the preliminary stages of an action research project for the design, development and assessment of a computer-based game for student learning about project risk management. A computer game was created through the use of systems dynamic software (Simsoft) incorporating a land development project. The game was played by final year undergraduate construction management students who had to make decisions in identifying, assessing and managing project risks. A survey of their experience found: that most students had not experienced this form of online educational game previously in their studies despite the ubiquity of information technology for learning purposes in the university sector; there was no strong support for the idea that the acquisition of knowledge was better compared to conventional learning through lectures and books; the computer-based experience was enjoyable thus indicating it drew them into the learning environment; and student testing found they had gained understanding of the project risk management process.
\end{abstract}

Keywords: Computer game, project risk management, Simsoft

\section{Introduction}

This paper reports the preliminary stages of an action research project for the design, development and assessment of a computer-based game for student learning about project risk management. Games are places to try new ideas and to experiment with established theories (Feldman 1995) and to try different things and where more might be learned from failure than success (Hung et al. 2009). Key elements common to games are (Suits 2005):

- Objective: A game has an objective i.e. a specific achievable state of affair, such as crossing the line first or scoring the most points. Objectives differentiate games from other types of play.

- Means: legal or legitimate ways of trying to achieve the objective of a game. Using a weapon in a boxing match is one way of achieving the goal of downing an opponent, but it is illegal.

- Rules: the legitimate means of achieving the objective of a game.

- Illusory attitude: a free-willed acceptance by players of the conceit created by seemingly arbitrary rules simply in order to participate in the games.

Caulfield's (2011) review into the instructional value of games identified two themes. First, learning objectives need to be clearly defined and built into the game (Becker 2011). Secondly, games are usually able to capture the attention of players and draw them into the 
learning environment. Games provide the opportunity for satisfaction of self-discovered knowledge, a richer and more varied learning experience, and the ability to rewind the play and try again without hurt. The favoured contemporary medium for games, computers, make it possible to implement games of richness presented through a multi-media interface. This richness may overwhelm or discourage participants (Hays 1989), so there needs to be an appropriate balance between technology and game elements (Meadows 1989). Caulfield (2011) found that games are not orders of magnitude better (nor worse) than other pedagogical methods.

Games come in many forms. Caillois (1961) proposed a classification that depends on whether the role of competition (agôn), chance (alea), simulation (mimicry), or vertigo (ilinx) is dominant. Agôn are those games that would seem to be competitive artificially in order that the adversaries should confront each other under ideal conditions e.g. football, chess. Alea are games of chance such as roulette or a lottery. Games of mimicry involve the players becoming other characters, such as cowboys and Indians. While ilinx are games that consist of an attempt to momentarily suspend the stability of perception and inflict a kind of panic upon an otherwise lucid mind.

\section{Project Risk Management}

The computer game described in this paper intends to facilitate learning in project risk management. Risk has been defined as the effect of uncertainty on objectives (ISO 2009), or more specifically as something bad that could happen (Hubbard 2009). Risks are present in all projects, whatever their size and complexity and whatever industry or business sector. Project risk management is fundamentally a decision-making process that should be structured and formal and applied throughout the project life cycle (Standards Australia 2009). Project risk management consists of the following processes (ISO 2009)

- Context: Risk management defines internal and external factors to be taken into account when managing risk. This sets the scope for the risk management processes.

- Risk Identification: This entails identification of potential risk events that may affect the successful attainment of project objectives. Risk identification should culminate in a list of risks that then need to be assessed.

- Risk Assessment: Identified risks are evaluated in terms of their potential consequences and probability of occurrence.

- Risk Treatment: Once the project risks have been identified and assessed then suitable strategies are adopted to manage them.

- Implementation and Control: The selected strategies must be implemented, monitored, controlled and reviewed.

\section{Research Design and Implementation}

This research is primarily based on the application of action research using a case study. Action research involves the identification of planned action, which is implemented and then systematically submitted to observation and reflection (Burns 2000). Action research is a means of injecting innovatory approaches to teaching and learning (Burns 2000). The

Baccarini, D., Xia, J. and Caulfield, G. (2012) 'The planning and implementation of computer-based games for project risk management education - a preliminary case study', Australasian Journal of Construction Economics and Building, Conference Series, 12 (1) 20-30 
problem to be researched is the use of computer-based games to achieve effective learning in project risk management within an undergraduate construction degree program.

Burns (2000) sets out the stages of action research. Key activities include:

- Identification of a general idea i.e. how to apply computer-based games to achieve effective learning in project risk management

- A literature review on the area of research i.e. computer games, project risk management

- Implementation of the action plan and interpretation and evaluation of the outcomes. This paper will use a case study to investigate the use computer-based games to achieve effective learning in project risk management

- Evaluation of the action research project. A questionnaire was completed by students after they had completed the computer-based game

- Interpretation and reflection of the outcomes were recorded by means of writing a case study, which is reported in this paper.

\section{Creation of the game}

The computer game reported in this paper is a subset of Caillois’s (1961) agôn classification, which aims for more than simple amusement and is designed to educate, train, or inform players (Michael \& Chen 2005; Schrage \& Peters 1999). The game was created by an action research team of three members (authors of this paper). One member was an expert of the software (Simsoft) used to create the computer game. The other two members were academic staff with expertise in project management and project risk management. Furthermore, one of them teaches and consults in project risk management. The computer game is based on a scenario developed from an actual land development project, where one of the authors had direct involvement in developing a risk management plan. The game entailed the application of the project risk management processes of identification, assessment and treatment.

The game is structured by project life cycle phases e.g. planning, design, construction. At each phase students are given a risk scenario and required to make decisions through the selection of multiple-choice options. After students answered each question, immediate feedback is provided by the computer game to inform whether their answer is correct or not and why. Based on their answers, students gain or lose marks.

The research sample were 4th (final) year students in the undergraduate degree B.AppSc (Construction Management \& Economics) at Curtin University. The game was played whilst undertaking a unit where students learnt the basic processes of project risk management. So before playing the game, students were provided with the theory of project risk management processes in class lectures. After the lecture the students played the game individually in front of a computer, either on or off campus.

The game was developed based on key elements common to games (Suits 2005):

- Objective: A game must have an objective. The objective of the game is the manage risk in a specific project scenario as effectively as possible.

- Means: legal or legitimate ways of trying to achieve the objective of a game. The game was designed to restrict options of decisions to legitimate methods.

Baccarini, D., Xia, J. and Caulfield, G. (2012) 'The planning and implementation of computer-based games for project risk management education - a preliminary case study', Australasian Journal of Construction Economics and Building, Conference Series, 12 (1) 20-30 
- Rules: the legitimate means of achieving the objective of a game. The game set out the rules and instructions that must be followed to complete the game. The software allowed no deviations

- Illusory attitude: a free-willed acceptance by players of the conceit created by seemingly arbitrary rules simply in order to participate in the games. All students voluntarily undertook the game, thus it could be implied that accepted the games and its rules

The game design contained two themes identified by Caulfield's (2011) for the instructional value of games:

- Learning objectives need to be clearly defined and built into the game. The objective of the game is to manage risk in a specific project scenario as effectively as possible. Points were awarded for correct risk management decisions that displayed achievement of the game's objectives

- Games should capture the attention of players and draw them into the learning environment. This was to be discerned by a questionnaire post-game to identify whether the users felt engaged by the game (reported herein).

As advised in the literature, the learning objectives for the game were defined and built into the game (Becker 2011). In general, learning objectives are statements that describe the knowledge, skills and attitudes that students should take away from any particular learning process. This project used Bloom et al.’s (1956) cognitive taxonomy to help formulate the learning objectives, in particular Bloom's “application' objective i.e. use previously-learned material in new situations. The objective of the game was to apply the project risk management knowledge and skills in a new situation i.e. computer-based game. Students were required to apply the knowledge and skills they learned in lectures to a computer-based game to manage specific risks in the designed scenario. The computer game allowed students to gain hands-on experience from a real life project scenario and obtain automatic immediate expert feedback to their answers

\section{Games content}

System dynamics is concerned with creating models or representations of real world systems of all kinds. A bespoke computer game called Simsoft was developed. Two key parts of Simsoft are the system dynamics engine that captures the fundamental causal relationships of the project being modelled, and a Java dashboard through which the players entered their risk management decisions and received feedback. Java also provided a means of saving the players individual decisions so these could later be analysed and replayed. The creation of the Simsoft computer modelling is described in detail in Caulfield et al. (2011). Students downloaded the game to their computer and run it as many times as needed. Figure 1 shows the initial screen of the game.

Baccarini, D., Xia, J. and Caulfield, G. (2012) 'The planning and implementation of computer-based games for project risk management education - a preliminary case study', Australasian Journal of Construction Economics and Building, Conference Series, 12 (1) 20-30 


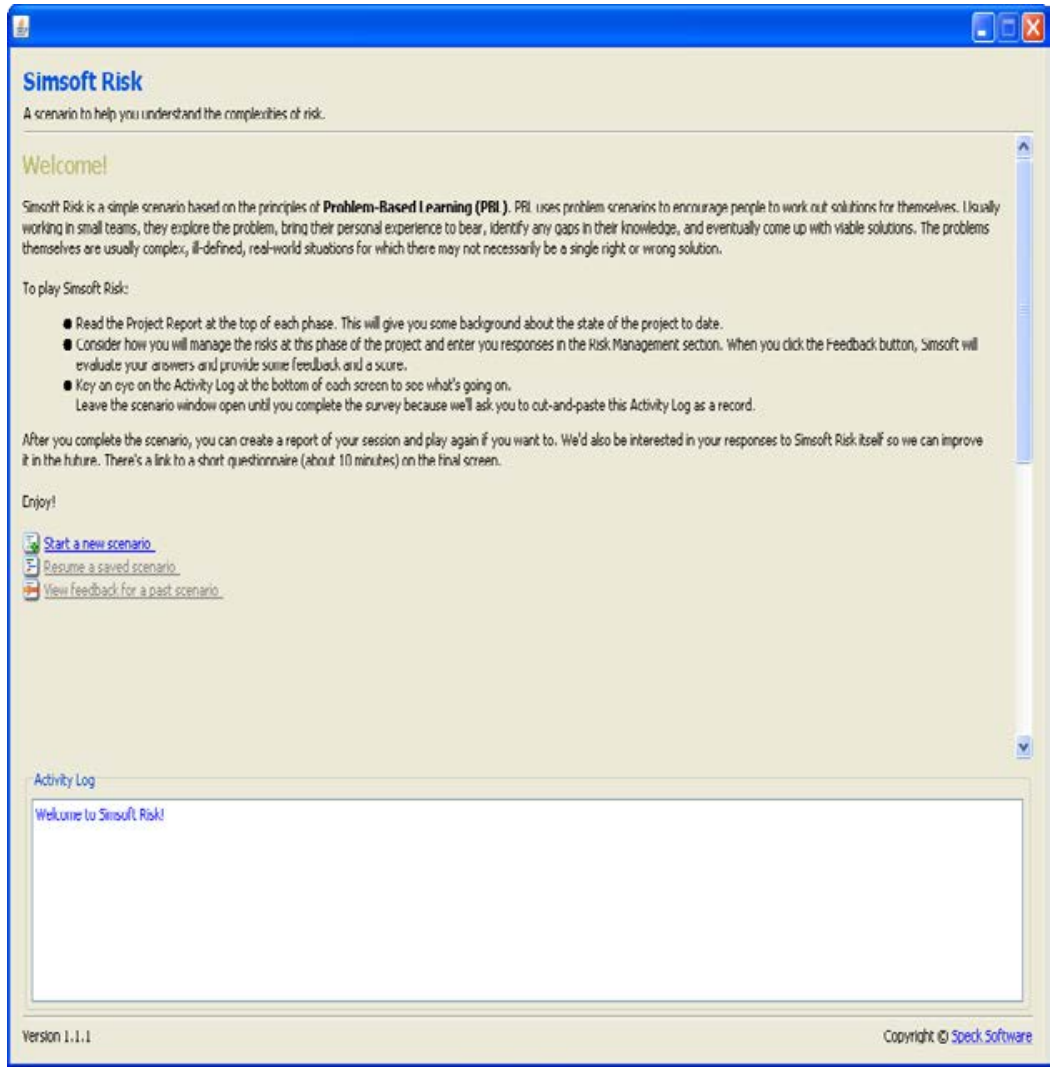

Figure 1: Simsoft welcome screen

The first page of the game provides the context set out in Figure 2

Project Title: Broome North Land Development project

Broome is experiencing major population growth and there is there severe shortage of residential lots. A land developer owns land in Broome North. The scope is the development of 700 hectares of land into 8,000 residential lots, with related infrastructure e.g. roads, utilities, retaining walls, landscaping. The development is in the Shire of Broome, $4 \mathrm{~km}$ north of the town centre. The main phases are: Planning \& Approvals \& Design; Procurement;

Figure 2: Computer Game Content - Context

The player is stepped through the phases of the project in sequence. In Phase One (Planning, Approvals, and Design) the first risk scenario is presented - see Figure 3. This first risk scenario of the game mimics the identification process within project risk management. The player first has to select one risk for a set of possible risks events (Figure 3). The three risk events and the expert feedback were created by one of the authors, who is a subject matter expert in project risk management and was involved in the actual project used for the computer game. Once the player selects one of the options, immediate pre-determined feedback is provided regarding whether their answer is correct or not and why (Figure 4).

Baccarini, D., Xia, J. and Caulfield, G. (2012) 'The planning and implementation of computer-based games for project risk management education - a preliminary case study', Australasian Journal of Construction Economics and Building, Conference Series, 12 (1) 20-30 


\section{Risk Scenario \#1 - Planning \& Approvals \& Design}

The estate design must be sensitive to the culture of the traditional aboriginal owners and must have overall strong connection to country. The support of these traditional owners is critical to the smooth implementation of the project. Recent similar projects conducted by the same developer in the North West of Western Australia have had some difficulties in meeting traditional aboriginal owners' requirements. Any problems with obtaining traditional aboriginal owners' acceptance may result in extensive negotiations and adverse effects on project cost and time

Which of the following could be a possible risk event during the planning / approvals / design phase, based on the information above?

1. traditional aboriginal owners do not support the proposed design

Figure 3: Computer Game Content - Risk Identification

\begin{tabular}{|l|l|}
\hline Player's selected answer & Feedback provided to player \\
\hline $\begin{array}{l}\text { traditional aboriginal owners } \\
\text { do not support the proposed } \\
\text { design }\end{array}$ & "Correct". You have 10 marks. Go on to analysing the risk \\
\hline $\begin{array}{l}\text { traditional aboriginal owners } \\
\text { protest during the } \\
\text { construction process }\end{array}$ & $\begin{array}{l}\text { "Incorrect'. This is a risk in construction phase, not the } \\
\text { design phase. You have not identified the risk. An } \\
\text { unidentified risk is not managed. The risk has eventuated and } \\
\text { the aboriginals protest against the design. You now have to } \\
\text { pay \$20,000 to Aboriginal consultants to manage these } \\
\text { dissatisfied stakeholders. Lose } 10 \text { marks }\end{array}$ \\
\hline $\begin{array}{l}\text { traditional aboriginal owners } \\
\text { kidnap the designers }\end{array}$ & $\begin{array}{l}\text { "Incorrect". Risk management must be practical. Only } \\
\text { sensible risks with some level of likelihood should be } \\
\text { identified. There has been no past history of traditional } \\
\text { aboriginal owners kidnapping people. You have not } \\
\text { identified the risk. An unidentified risk is not managed. The } \\
\text { risk has eventuated and the aboriginals protest against the } \\
\text { design. You now have to paid \$20,000 to Aboriginal } \\
\text { consultants to managed these dissatisfied stakeholders Lose } \\
10 \text { marks }\end{array}$ \\
\hline
\end{tabular}

Figure 4: Computer Game Content - Risk Identification - Feedback

The next question in the risk scenario mimics the assessment process within project risk management. The players next had to assess:

- the likelihood of the risk event occurring (either: almost certain, likely, possible, unlikely, or almost impossible) (Figure 5), and

- the consequences might be (either: catastrophic, major, moderate, minor, insignificant).

Again, predetermined expert feedback is provided to the player's selected response.

Baccarini, D., Xia, J. and Caulfield, G. (2012) 'The planning and implementation of computer-based games for project risk management education - a preliminary case study', Australasian Journal of Construction Economics and Building, Conference Series, 12 (1) 20-30 


\begin{tabular}{|c|c|}
\hline Player's selected answer & Feedback provided to player \\
\hline $\begin{array}{l}\text { What is the likelihood of } \\
\text { your selected risk event } \\
\text { occurring? } \\
\text { - rare, } \\
\text { - unlikely, } \\
\text { - possible } \\
\text { - likely } \\
\text { - almost certain }\end{array}$ & $\begin{array}{l}\text { If 'likely' or 'possible' chosen, = 'correct'. You have } 10 \\
\text { marks } \\
\text { If 'almost certain' chosen, = incorrect. As this developer has } \\
\text { conducted similar projects in the recent past, it is reasonable } \\
\text { to expect that they would undertake actions to minimise the } \\
\text { likelihood of this familiar risk. Lose } 10 \text { marks } \\
\text { If ‘unlikely' or 'rare', = 'Incorrect”, as this is a cultural } \\
\text { sensitive project and one would reasonably expect a strong } \\
\text { likelihood of some problems. Lose } 10 \text { marks Feedback } \\
\text { provided to player }\end{array}$ \\
\hline
\end{tabular}

Figure 5: Computer Game Content - Risk Assessment - Feedback

After reflecting on this feedback, the players move onto the next phase of the project. There are further phases in the game that are not elaborated upon in this paper.

\section{Survey - Results and Analysis}

A post-game online questionnaire was completed by the players, to gauge the game's effectiveness as a learning tool and to indicate future improvements. Post-game surveys are a common feature of game research (Faria \& Wellington 2004). Twenty-six students completed the survey, 16 males and 10 female. The dominance of male students is not unexpected in a construction orientated degree, which have traditionally attracted a majority of male students. Over $90 \%$ of students were under 22 years of age, which puts them into the Generation Y category, the term generally applied to people born in the1980s and early 1990s, and generally characterized by an increased use and familiarity with communications, media, and digital technologies

Students were asked “Have you experienced this type of online learning before?” (See Table 1).

Table 1: Previous experience with online learning

\begin{tabular}{|l|l|}
\hline $\begin{array}{l}\text { Have you experienced this type of online } \\
\text { learning before? }\end{array}$ & $\mathrm{Nr}$. \\
\hline No & 19 \\
\hline Yes & 7 \\
\hline
\end{tabular}

This strong 'no' result might be seen as surprising. The advancement in the use of technology in business generally, and in university degree courses specifically, has grown in recent times. For example, universities are promoting the provision of online learning and the ubiquitous use of online course management software such as Blackboard $\subset$. Furthermore, today's generation of university students, often referred to as Generation Y, have grown up in an online environment through use of media tools such as Facebook@ and Twitter@. These results suggest the universities are still in the infancy of using online technologies particularly in the development on online games for learning purposes. Commonly, games have been found to be more expensive and administratively demanding to

Baccarini, D., Xia, J. and Caulfield, G. (2012) 'The planning and implementation of computer-based games for project risk management education - a preliminary case study', Australasian Journal of Construction Economics and Building, Conference Series, 12 (1) 20-30 
develop and use than some other forms of instruction (Petranek 1994; Gredler 2004). So this could discourage lecturers to produce computer-based games for learning. For example more effort and time is needed in the preparation of games, compared with cases and text alone (Knotts \& Keys 1997).

Two questions were asked to gauge the effectiveness of online games for learning.

Have you learnt the material through the game better than conventional ways e.g. books, lectures? (Table 2)

Table 2: learning experience through computer game

\begin{tabular}{|l|c|c|c|c|}
\hline Question & $\begin{array}{c}\text { not } \\
\text { really }\end{array}$ & $\begin{array}{c}\text { Some } \\
\text { what }\end{array}$ & $\begin{array}{c}\text { very } \\
\text { much }\end{array}$ & $\begin{array}{c}\text { Don't } \\
\text { know }\end{array}$ \\
\hline $\begin{array}{l}\text { Have you understood the material through the } \\
\text { game better than conventional ways e.g. books, } \\
\text { lectures? }\end{array}$ & 7 & 10 & 4 & 5 \\
\hline
\end{tabular}

The responses are ambivalent. It might reasonably be anticipated that today's generation of university student would positively engage in online games as a mode of learning. However, only just over 50\% (14 of 26) of respondents considered the learning somewhat or very much better than conventional ways of learning. One reason could be that was this was first version the game, which focused on incorporating the basic content such as project description, questions and feedback. Time and effort was not devoted to enhancing visual or animation dynamics. Computers make it possible to implement games of richness presented through a multi-media interface. This suggests possible future improvement in the presentational style of the game.

The game was enjoyable (Table 3).

Table 3: enjoyment experience through computer game

\begin{tabular}{|l|c|c|c|}
\hline Question & agree & disagree & don't know \\
\hline The game was enjoyable & 18 & 3 & 5 \\
\hline
\end{tabular}

The strong agreement with this statement suggests that today's university students are drawn towards computer-based activities generally and games specifically. It is axiomatic that students are more likely to participate in learning activities that offer an enjoyable experience. These results provide encouragement to lecturers to explore the use of computer games as a means of learning and student engagement. The literature indicates that games are usually able to capture the attention of players and draw them into the learning environment (Caulfield, 2011).

A set of questions were asked to gauge how well learning has been facilitated by undertaking the computer game (Table 4).

Baccarini, D., Xia, J. and Caulfield, G. (2012) 'The planning and implementation of computer-based games for project risk management education - a preliminary case study', Australasian Journal of Construction Economics and Building, Conference Series, 12 (1) 20-30 
Table 4: measuring learning [Note: Grey = correct answer]

\begin{tabular}{|l|c|c|c|}
\hline Question & agree & disagree & don't know \\
\hline High risks should be mitigated & 24 & 0 & 2 \\
\hline $\begin{array}{l}\text { Risk management is a structured } \\
\text { process }\end{array}$ & 26 & 0 & 0 \\
\hline
\end{tabular}

Students were provided with lectures on project risk management prior to the workshop. The responses in Table 4 shows a very high proportion of correct answers, which suggests that the quality of the lectures, reinforced by undertaking the game, has resulted in strong learning. This indicates that games can be used effectively to underpin knowledge already gained, as in this game. Games could also be used to introduce new knowledge but that was not the objective of this preliminary research project. This suggests a research opportunity exists to provide the game to students who have not had the prior lectures and assessing the learning value.

\section{Reflection and Conclusion}

This paper reported the preliminary stages of an action research project for the design, development and assessment of a computer-based game for student learning about project risk management. The results are preliminary and based on a small sample. So any conclusion must necessarily be tentative. Further research will be based on a larger sample to provide more valid results. Action research requires reflection upon the research outcomes. The following reflections are made.

The use of information technology is growing rapidly in all fields of human endeavour. It is commonplace in universities to offer courses fully online, which facilities the delivery of material such as lecture notes, PowerPoint and recorded lectures. A relatively small number for students in the research sample had previously experienced the use of computer games for learning. This suggests that the provision of bespoke computer games to facilitate learning in university degree program appears to be it in infancy. A possible reason could be the significant effort required on behalf of academic staff and computer specialists to produce bespoke games. This effort acts as a deterrent to their creation. The authors can report that an extensive amount of hours was expended in creating this first version of this computer game and appreciate that academics may approach warily the chance of conducting a similar project. This suggests that academics perhaps should research the availability of generic 'off-the-shelf solutions, where they exist. However, the more specific the learning objective such as the application of project risk management to construction projects, the more likely that a bespoke solution will be required.

University students, such as Generation $\mathrm{Y}$ who dominate the present cohort of university undergraduates, are comfortable with interacting with computers generally, and engaging in games specifically. It could be that students' expectations are for universities to provide a dynamic, interactive learning experience through the use of information technology. The survey found that a majority of students enjoyed the experience, which indicates that are drawn towards the learning experience. This should provide encouragement for lecturers to pursue the development and use of computer-based games for student learning.

Baccarini, D., Xia, J. and Caulfield, G. (2012) 'The planning and implementation of computer-based games for project risk management education - a preliminary case study', Australasian Journal of Construction Economics and Building, Conference Series, 12 (1) 20-30 
The survey results indicate that the computer game provided a valuable learning experience, in terms of reinforcing knowledge and engaging students in learning. Immediate feedback provided to students after each risk decision is a powerful facility for underpinning and affirming correct understandings about the project risk management process, and for quickly rectifying misunderstandings supported by reasons. This immediacy between a student's answer and assessment by computer response is a typical facility of information technology that is powerful and attractive to students. The variable responses to the question "Have you understood the material through the game better than conventional ways e.g. books, lectures?” suggests students still have some preference for the conventional classroom delivery of knowledge, perhaps because it provides a face-to-face opportunity for students to clarify and question understanding with their peers and the lecturer. This implies that the computer game may be best undertaken in a group computer laboratory session attended by the lecturer, rather that the individual online process of this project.

One unexpected benefit of the project was the discipline required by the action research team to produce the pre-determined feedback linked to students' answers. This required reflection of the authors' expertise and the need to articulate their knowledge through the feedback written into the computer program. The resulted in a deeper understanding of their expert knowledge and development of new insights.

The next phase of the research project is to develop the computer game in various ways. One consideration is the introduction of a more exciting interface with perhaps some animation and colour, in order to make it more attractive to students. Another consideration is run the game prior to students being provided with any lectures in project risk management to gauge its effectiveness as a learning tool for introducing new knowledge. Furthermore, the game will be run in a group computer laboratory session so that the lecturer can provide immediate feedback to supplement the game's feedback and then evaluate the effectiveness of student learning. The game is it in its embryonic phase and primarily linear in nature i.e. students move in a sequential manner from one situation to the next. The new phase will be to explore the possibilities of creating alternative routes through the game

\section{References}

Becker, K. (2011). 'The Magic Bullet: A Tool For Assessing The Evaluating Learning Potential In Games.' International Journal Of Game-Based Learning. 1, 19 - 31.

Bloom, B.S., Masia, B.B. \& Krathwohl, D.R. (1956). Taxonomy Of Educational Objectives:

The Classification Of Educational Goals (Handbook I: Cognitive Domain Ed.), Longman London.

Burns R.B. (2000). Introduction To Research Methods, Longman, London

Caillois, R. (1961). Man, Play And Games (M. Barash, Trans.), Free Press Of Glencoe, New York.

Caulfield, C.W. (2011). Shall We Play A Game? Unpublished Phd Thesis, Edith Cowan University, Perth.

Caulfield., C.W., Veal, D. \& Maj, S.P.(2011). 'Implementing System Dynamics Models In Java.' International Journal Of Computer Science And Network Security, 11, 43-49.

Baccarini, D., Xia, J. and Caulfield, G. (2012) 'The planning and implementation of computer-based games for project risk management education - a preliminary case study', Australasian Journal of Construction Economics and Building, Conference Series, 12 (1) 20-30 
Feldman, H.D. (1995). 'Computer-Based Simulation Games: A Viable Educational Technique For Entrepreneurship Classes?' Simulation \& Gaming, 26, 346 - 360.

Gredler, M.E. (2004). 'Games And Simulations And Their Relationships To Learning', In Handbook Of Research On Educational Communications And Technology, $2^{\text {nd }}$ Edition, Ed., Jonassen, D.H., Lawrence Erlbaum Associates Publishers, New Jersey, Pp. 571 581.

Hays, R.T. (1989). Simulation Fidelity In Training System Design: Bridging The Gap Between Reality And Training. Springer-Verlag, New York.

Hubbard, D. W. (2009). The Failure Of Risk Management, Wiley, New Jersey.

Hung, D., Chen, V. And Lim, S. (2009). 'Unpacking The Hidden Efficacies Of Learning In Productive Failure.’ Learning Inquiry, 3(1), 1 - 19.

Iso. (2009). Iso 31000: Risk Management - Principles And Guidelines, Geneva, Iso.

Knotts, U.S. \& Keys, J.B. (1997). 'Teaching Strategic Management With A Business Game.' Simulation \& Gaming, 28, 377 - 394.

Meadows, D.L. (1989). 'Gaming To Implement System Dynamics Models', In ComputerBased Management Of Complex System, Eds., P. M. Milling And E. O. K. Zahn Springer-Verlag Berlin, Pp. 635 - 640.

Michael, D. \& Chen, S. (2005). Serious Games: Games That Educate, Train, And Inform, Thomson Course Technology Ptr, Boston.

Petranek, C.F. (1994). 'A Maturation In Experiential Learning: Principles Of Simulation And Gaming.' Simulation \& Gaming, 25, 513 - 522.

Schrage, M. \& Peters, T. (1999). Serious Play: How The World's Best Companies Simulate To Innovate, Harvard Business School Press, Boston.

Standards Australia (2009). Risk Management. As/Nzs 31000:2009. Sydney, Nsw.

Suits, B. (2005). 'Construction Of A Definition', In The Game Design Reader, Eds., K. Salen \& E. Zimmerman, The Mit Press, Cambridge, Massachusetts, Pp.172 - 191.

Baccarini, D., Xia, J. and Caulfield, G. (2012) 'The planning and implementation of computer-based games for project risk management education - a preliminary case study', Australasian Journal of Construction Economics and Building, Conference Series, 12 (1) 20-30 